\title{
THE LAW OF REAL PROPERTY
}

R. E. Megarry, Q.C., M.A., LL.D.(Cantab.), Hon.LL.D.(Huil). A Bencher of Lincoln's Inn, Book Review Editor of The Law Quarterly Review; Reader in Equity in the Inns of Court

H. W. R. Wade, LLD., D.C.L. of Lincoln's Inn, Barrister-at-Law; Professor of English in the University of Oxford

3rd Edition

As was said of the previous edition, "the book can be recommended, without reservation, both as the principal text book of every student of real property who aspires to more than a nutshell knowledge of his subject, and as a work of reference worthy of an accessible position on the practitioner's shelves".

The general plan of the work remains unaltered, but there has been a major change within that pian. In order to improve the speed of reference, and to make the contents more easily digestible, the system of subheadings throughout the work has been revised and many of the longer passages have been sub-divided and sub-titled.

Price in U.K. 25 5s. net. Postage 4s. 6d.

\section{SNELL'S PRINCIPLES OF EQUITY}

R. E. Megarry, Q.C., M.A., LL.D.(Cantab.), Hon.LL.D.(Huli) A Bencher of Lincoln's Inn, Book Review Editor of The Law Quarterly Review; Reader in Equity in the Inns of Court

AND

P. V. Baker, B.C.L., M.A.

of Lincoln's Inn, Barrister-at-Law; Lecturer in the Law of Land in the Inns of Court; Assistant Editor of The Law Quarterly Review

26th Edition

In the new edition passages have been completely rewritten. In particular this applies to the sections on charities, constructive trusts, trustee investments, variation of trusts, tracing, distribution of assets, Interest on legacles and apportionment, the discharge of mortgages, satisfaction, married women, infants and equitable estoppel.

Price in U.K. f3 17s. 6d. net. Postage 5s. Od.

\section{SALMOND ON JURISPRUDENCE}

F. J. Fitzgerald, M.A.

of Lincoln's Inn, Barrister-at-Law; Professor of Law in the University of Leeds 12th Edition

Throughout this new collection, the Editor has concentrated on essentials, avoided excessive detail, and aimed to provide a textbook which is not too difficult but which fully accepts the challenge of approaching this subject in the light of recent developmente. Paperback edition available.

Price in U.K.: Hardback 23 5s. net. Postage 2s. 3d. Paperback \&1 12s. 6d, net. Postage 1s. 9d.

\section{SWEET \& MAXWELL-STEVENS} 11 New Fetter Lane, London E.C.4 


\section{Odgers: Principles of Pleading and Practice in Givil Actions in the High Court of Justice}

Giles Francis Harwood, M.A.

of the Inner Temple and Western Circuit, Barrister-at-Law

Basil Antony Harwood, M.A.

of the Inner Temple, Barrister-at-Law; Senior Master of the Supreme Court, and Queen's Remembrancer

19th Edition

"No one, student or practitioner (for this is one of those books which the student carries over into his practising days), can rely on the earlier editions, except, of course, for comparative purposes to examine the evolution of the subject," wrote a reviewer of the last edition (Modern Law Review).

These words are always in every way true of this new edition, which presents a comprehensive and authoritative explanation of the most upto-date law for student and practitioner use.

Price in U.K. £3 10s. net. Postage 2s. $9 d$.

\section{Modern Trade Union Law}

Cyril Grunfeld, M.A., LL.B.(Cantab.) of the Inner Temple, Barrister-at-Law; Professor of Law Designate in the University of London (London School of Economics and Political Science) Written clearly and concisely from an expert and informed viewpoint, the book is designed to provide for the student of law, business, commerce and politics, a clear summary and explanation of the principles involved. Always readable and based firmly on current problems, the work lays a basis for informed discussion. Fully up to date, including a summary of the controversial Trade Disputes Act 1965, the book can be recommended for all who require a sound working knowledge of modern trade union law and practice.

Price in U.K. $£ 2$ 5s. net. Postage 2s. $3 d$.

\section{The Law of Contract}

G. H. Treitel, B.C.L., M.A.

of Grays Inn, Barrister-at-Law; Fellow of Magdalen College, Oxford;

All Souls Reader in English Law

2nd Edition

"... the merit of the work lies in the quite simple fact that the general principles of the law are stated in a clear and concise way while at the same time the author has managed to combine this clarity with a high standard of scholarship."-Modern Law Review

Price in U.K.: Paperback $£ 1$ 18s. 6d. net. Postage 2s. Od. Hardback $£ 3$ 17s. 6 d. net. Postage 3s. Od.

\section{SWEET \& MAXWELL-STEVENS \\ 11 New Fetter Lane, London E.G.4}

PUBLBHED BY DUTTRRWORTH \& CO. (PUBLSHRRS) LTD., 88 KINGSWAY, LONDON, W.C.2. PRINTED IN GRAT BRITANN BY THE THANET PREg, MARGATE 